\title{
Cherry-picking external constraints: Latvia and EU economic governance, 2008-2014
}

Edgars Eihmanis (EUI)

Accepted for publication at Journal of European Public Policy

Keywords: EU economic governance, European Semester, crisis, euro accession, conditionality, social policy

Word count: 7920 (all included)

\begin{abstract}
The paper analyses Latvian economic policy during the period of 2008-2014 when the country was simultaneously subject to three EU economic governance frameworks - the European Semester, the Balance-of-Payments (BoP) programme and the Maastricht convergence criteria (for euro adoption). Through in-depth process tracing based on public policy documents, interviews with senior officials in Riga and Brussels and the press, the paper finds that the Latvian government cherry-picked and instrumentalised EU economic policy targets and overachieved them. In contrast to the literature depicting the European Commission as a neoliberal actor which systematically undermines social protection, the paper shows that against the backdrop of fiscally austere national authorities, the Commission instead played the role of social policy advocate, repeatedly calling for stronger measures to help the poor. Shedding light on the limits of one-size-fits-all governance, the findings of the Latvian case have significant implications for EU economic governance more generally.
\end{abstract}




\section{Introduction}

Since the onset of the economic crisis, European Union (EU) economic governance has become increasingly complex. The European Commission initiated a set of new economic governance tools, considerably narrowing down the discretionary powers of individual member states. Besides strengthening and enforcing fiscal discipline, frameworks such as the Fiscal Compact, the Two-Pack, the Six-Pack, and the Euro-Plus Pact controlled for macroeconomic imbalances in a range of policy areas, such as housing, current account balance, and labour competitiveness, among many others. All these initiatives were incorporated into the European Semester - itself a framework designed to enhance the effectiveness of economic governance (Bekker 2013; Laffan and Schlosser 2015). However, over the course of the crisis, the Commission's management of the crisis in general and the EU economic governance architecture in particular have been criticized as fundamentally neoliberal, operating to undermine the welfare state (cf. Joerges 2014).

Some critics are concerned that European social security systems have become a mere adjustment variable for Economic and Monetary Union (EMU) (Degryse et al. 2013; Pochet and Degryse 2012; Scharpf 2014: 143), and/or that the crisis might even lead to the end of the European Social Model (Hacker 2012). Others have argued that 'governing by the rules and ruling by the numbers', the 'new EU economic governance' framework exacerbated the social problems created by the crisis, as budget deficit reductions with pressure for structural reforms came at the expense of labour protection (Crespy and Menz 2015: 10; Schmidt 2014, 2015). Finally, the Commission has been heavily criticized for its management of the Balance-of-Payments and Economic Adjustment programmes. The overwhelming focus on austerity as a means to regain economic growth, and - as a consequence - the neglect of social policy, has even been lambasted by its in-house auditors and the International Monetary Fund (IMF) (European Court of Auditors 2015; Spiegel et al. 2015). According to 
Lütz and Kranke (2010), the conditionality imposed on Hungary, Latvia and Romania amounted to a 'European rescue of the Washington Consensus' (Lütz and Kranke 2014). Specifically focusing on crisis resolution in the Baltic countries, Woolfson and Sommers (2016) argue that the undeviating commitment to strictly neoliberal disciplinarian terms by the current European Commission and the international financial community has been an ultimate social and economic failure (Woolfson and Sommers 2016: 90).

Analysing Latvia's economic governance simultaneously under the Balance-of-Payments programme, euro convergence and the European Semester, the paper aims to provide a more balanced view of the Commission's stance on social policy. Drawing on interviews with senior officials in the Latvian government and Commission, public policy documents and the press, I find that against the backdrop of national authorities pursuing radical market-oriented policies, the Commission played the role of social policy advocate. In fact, the Latvian government cherry-picked and instrumentalised EU fiscal rules, overachieving them well beyond the targets set by the Commission. Avoiding any additional spending even when allowed by the Fiscal Compact and the Balance-of-Payments (BoP) programme, the authorities instead focused on early payment of the bailout loans. Similarly, in order to increase the chances of meeting the Maastricht inflation criterion, the government cut Value Added Tax (VAT), thus postponing a long-pending social reform.

While endorsing the excessive fiscal consolidation pursued by the national authorities, as it helped to securitize against uncertainty, the Commission also consistently expressed social concerns. Together with the World Bank and the IMF, the Commission repeatedly called for stronger measures to help the poor and vulnerable. Moreover, besides showing how the Commission advocated for additional targeted measures, the paper shows several instances where the Commission economists called for more social spending in absolute terms. First, the Commission opposed the government decision to cut VAT (to curb inflation), as this eliminated the fiscal space to help lower income earners. Second, the Commission economists stated that they were ready to accept more social spending from any windfall revenue in the budget - as was allowed by the Memorandum of Understanding in the first place. 
Finally, the paper shows how the Commission together with the World Bank and the IMF triggered a progressive change in Latvia's social policy. When the national authorities wanted to phase out the state co-financing of Guaranteed Minimum Income (GMI) benefits on the assumption that due to dependence on welfare benefits people were unwilling to work, the lenders - the largest of whom was the Commission - demanded evidence and forced the government to commission a study by the World Bank. The subsequent report significantly challenged the common wisdom on social policy among the Latvian elites, and served as a basis for policy change. A key contribution to the literature is thus that the Commission's persistent stance on Latvian social policy clearly goes beyond the sort of neoliberalism which is commonly assumed by many accounts of EU socio-economic governance since the crisis.

The Latvian case provides us with a unique opportunity to analyse the simultaneous operation of three distinct EU governance frameworks. First, facing a default in 2008, Latvia became subject to the Balance-of-Payments (BoP) programme. Subsequently, from January 2012 to January 2015, Latvia entered the post-programme surveillance phase, still subject to Commission scrutiny in order to 'closely monitor risks that could jeopardize macro-economic stability and hence affect the repayment capacity' (European Commission 2012c). Second, by 2011, as the BoP programme expired, the European Semester and Country-Specific Recommendations (CSRs) started to apply to Latvia. ${ }^{1}$ Finally, not wanting to renounce its commitment to join the euro area in 2014, Latvia sought to comply with the Maastricht convergence requirements on inflation, budgetary deficit, long-term interest rates and public debt.

Analysis of the Latvian case contributes to several important debates on EU post-crisis governance. First, it shows that the Latvian government was able to cherry-pick policy targets from various governance frameworks, justifying non-compliance in some areas with overcompliance in others. Second, in contrast to the literature that calls for a more enforceable social dimension at the EU level (e.g. Schoukens 2013; Vandenbroucke et al. 2013), the

\footnotetext{
${ }^{1}$ The European Semester is an annual cycle of economic policy coordination, according to which each year the Commission undertakes a detailed analysis of the member states' programmes of economic and structural reforms. It starts by the Commission, the Council and the European Council issuing the Annual Growth Survey. After reviewing the Commission's Country Reports and National Reform Programmes, the Commission and Council issue Country-Specific Recommendations (CSRs) (European Commission 2015b).
} 
evidence from the Latvian case does not support the view that more hierarchical governance would necessarily lead to better results. In fact, the Latvian authorities exercised considerable discretion not only in 'soft' policy areas, such as social assistance, but also in 'hard' fiscal policy areas such as taxation, budgeting and spending as well. Moreover, the Latvian case shows that hierarchically imposed ready-made rules not only fail to address adequately local needs and challenges, but can also be strategically misused by the governing élites.

The paper is organized as follows. First, I briefly review evaluations of EU economic governance since the crisis and introduce the analytical framework. Then, after reviewing the background to the economic crisis, I explore the Latvian fiscal and social policy making process, as the country was converging to the euro. I conclude by briefly drawing out the broader implications of the Latvian case for EU economic governance more generally.

\section{EU economic governance and 'uses of Europe'}

A central criticism of the enforced economic governance architecture has concerned the imbalance between fiscal and macroeconomic surveillance, on the one hand, and broader social policy, on the other (de la Porte and Heins 2014). While the macro-economic governance tools are based on pre-set numerical indicators and sanctions in the case of noncompliance, social policy continues by and large with the soft governance approach established by the Open Method of Coordination (Vandenbroucke et al. 2013: 5). However, the conceptual line between 'soft' and 'hard' governance may not be so sharp in practice. As argued by Trubek and Trubek (2005), with increased emphasis on experimentation, deliberation and discursive diffusion, 'soft' law may be 'harder' than it seems at first glance. In addition, due to implementation problems, 'hard' law on the books does not necessarily correspond to law in action (Trubek and Trubek 2005: 361). Thus, Bekker (2013) finds that since the crisis, the 'hardness' from the fiscal policy domain has to some extent spilled-over to the social policy domain - for instance, employment and social policy are increasingly evaluated from an economic or financial perspective (Bekker 2013: 9). The opposite dynamic is also visible. According to Vivien Schmidt (2014), rather than lending 'hardness' to the social domain, economic and fiscal governance itself has become more flexible and interpretation-based - if not admitted openly, than 'by stealth'. For instance, within the Excessive Deficit Procedure, public deficits were increasingly considered on a 'structural', 
rather than 'cyclical' basis, thus allowing for more fiscal space (Schmidt 2014: 8-10). However, beyond these enforcement dynamics, there is no doubt that in substantive terms EU economic governance has become increasingly socially balanced since the beginning of the crisis. If the 2011 Annual Growth Survey (AGS) prioritized rigorous fiscal consolidation, labour market reforms and growth enhancing measures, its successors provided a broader and more socially balanced set of priorities, which was further reflected in the European Semester (European Commission 2011, 2012a). The subsequent rounds of Country-Specific Recommendations (CSRs) proposed a variety of reforms in social security, pension, education and healthcare systems. Together with the intensification of social monitoring, multilateral surveillance and an enhanced role for social and employment policy actors, this has resulted in the 'progressive socialization' of the European Semester (Vanhercke et al. 2015; Zeitlin and Vanhercke 2014).

The paper shows how the national authorities in Latvia cherry-picked and instrumentalised various EU rules and recommendations, by using them as external constraint(s). A classic example of governing by external constraint or what Dyson and Featherstone (1996) call a vincolo esterno is Italy in the 1990s. In order to overcome the problem of obstructive party dominance, the Italian technocratic élite shared a belief in the need for externally imposed economic discipline, and found it in the euro conditionality (Dyson and Featherstone 1996). The EU anchor served a double function for Italy. First, it offered incentives for the reorientation of economic, social and political attitudes from below (related to the four freedoms of labour, goods, capital, and services). Second, it gave the élite precious resources from above to legitimize difficult policy measures. The combination of carrots (accession to EMU) and sticks (higher interest rates and currency depreciations whenever the markets expected Italy to devalue) led to significant upgrades in the organization of Italy's labour market, as well as in the fiscal and social policy domains (Ferrera and Gualmini 2004). I show that the Latvian authorities used similar 'hand-tying' strategies to pursue their preferred policies.

In order to establish the causal mechanisms involved, I trace the policy making process on the basis of three broad data sources (George and Bennett 2005). First, I conducted élite interviews with four economists at the Commission's Directorate-Generals for Economic and Financial Affairs (ECFIN), Employment, Social Affairs and Equal Opportunities (EMPL), 
three senior officials at the Latvian Ministries of Economics, Finance and Welfare, as well as Ilze Viṇķele, former Minister of Welfare (2011-2014). Second, I draw extensively on official documents from different policy coordination frameworks. For instance, within the European Semester, I analyse Country-Specific Recommendations, National Reform Plans, and Commission staff working documents. I also examine euro convergence reports (programmes), as well as the Balance of Payments programme reviews. Finally, I rely on the relevant press sources to follow the public debates.

\section{Economic crisis in Latvia}

On May 1, 2004 Latvia joined the EU, soon after pegging its currency to the euro. Investors' optimism abounded and the country was flooded with foreign capital. In the following years Latvia experienced double-digit real Gross Domestic Product (GDP) and inflation rates. Nominal wages doubled and property prices increased fourfold (European Commission 2012b: 3). However, in 2008, following the freeze of liquidity in the international markets and the collapse of Lehman Brothers, the overheated Latvian economy fell into recession. Needing to nationalize Parex, Latvia's second largest bank with the biggest domestic market share in the EU, the authorities turned to the IMF and the Commission for a bailout (Aslund and Dombrovskis 2011: 33-34). Rejecting advice from various internationally renowned economists and the IMF to devalue the currency (Krugman 2009; Lütz and Kranke 2014: 320; Roubini 2008), the government orchestrated a massive 'internal devaluation'. Framing austerity as 'virtuous pain after the immoral party' (Blyth 2013: 13), a new ethos was constructed: to avoid spending at any cost. A broad range of structural reforms were implemented. Among other things, the government closed half of the 75 government agencies and cut public salaries by 26 per cent (Aslund and Dombrovskis 2011: 72-73). Although, Latvian crisis management became a 'success story' in macroeconomic terms, the social costs were immense (Aslund 2013; Austers 2014; Lagarde 2012). In the first two years of the recession, the Latvian economy shrank by approximately a quarter. In 2010, unemployment rose to 20.7 per cent.

In order to push through the reforms, the Latvian authorities heavily relied on 'external constraints'. In his co-authored book How Latvia came through the crisis, Prime Minister (PM) Dombrovskis himself admits that the structural reforms were based on 'an international 
norm that made sense'. As regards the use of vincolo esterno, Dombrovskis is explicit: 'Luckily, the government did not have to invent these reforms hastily. They were well prepared and documented, primarily through studies the government had done with the World Bank. The government basically had to take these reform proposals off the shelf and start implementing them, and it did' (Aslund and Dombrovskis 2011: 72-73). Relatedly, as I show below, the bailout conditionality and the Fiscal Compact were welcomed by the Latvian government as tools for more rapid budget consolidation.

However, the economic recession had limited electoral effects on the distribution of political power. Despite the hardship imposed on the Latvian society, PM Dombrovskis was re-elected in 2010 and 2011. To a large extent this can be explained by the well-established 'ethnic cleavage with a corruption divide' (Auers 2013: 94). In brief, ethnic Latvians vote for mostly the centre-right Latvian parties depending on their stance of fighting corruption, while ethnic Russians vote for the centre-left Russian parties - which have so far been kept out of government. Latvia's politics during the recession closely follows these lines. Replacing the allegedly corrupt and profligate previous government, PM Dombrovskis formed a centreright cabinet with a two-fold agenda of fiscal consolidation and euro accession. To the extent that the consolidation measures were mostly contested by the Russian (not Latvian) opposition, the Latvian ruling coalition, and more specifically PM Dombrovskis and Finance Minister Vilks, were relatively free to pursue it. The same applies to euro accession. Aiming to further integrate in the EU and obtain security against the perceived threat of Russia, the Latvian authorities did not abandon the ambition to adopt the euro throughout the crisis (Dandashly and Verdun 2015: 5; Milne 2013). In economic terms, the authorities emphasized the significance of financial stability and market confidence which would likely lead to lower borrowing costs, increased investment and economic growth (Traynor 2012). Politically, euro accession was bundled together with Latvia's 'success story' of internal devaluation, where one continued the other.

\section{Governance in fiscal policy}

Latvia's fiscal policy during the crisis consisted in a chain of overachievements. The government voluntarily set more ambitious fiscal policy targets than required by the EU frameworks and the bailout conditionality, thus minimizing its spending options. Reviewing 
three major instances of self-imposed austerity, I show that the Latvian government pursued a more austere approach to fiscal consolidation than the lenders. First, the government repeatedly used the positive growth dynamics in its trade partners' economies to revise the budget targets; second, the government instrumentalised the most stringent version of the Fiscal Compact to maximize fiscal discipline; and third, the government did not take the advantage of windfall revenue as would have been permitted by the Balance-of-Payments programme.

In late 2010, the government projected a 2011 budget deficit at 5.4\% of GDP - a considerably lower target than the previously planned 6\%. By April 2011, adopting additional fiscal consolidation measures, the government reduced the deficit even further to $4.5 \%$ of GDP. The budget deficit target for 2012 was then set at $2.5 \%$ of GDP, thus overachieving the 3\% threshold, required by the Excessive Deficit Procedure (Ministry of Economics 2011: 10). By early 2012, the budget deficit target for 2012 was further reduced to $2.1 \%$ of GDP (Ministry of Economics 2012: 24). To a considerable degree overachieving the fiscal targets was enabled by 'better-than-expected economic growth', as Latvia took the advantage of the positive economic conditions in its main trading partners' economies and the slower development of some planned investment projects. To put it in the words of an ECFIN economist: 'to some extent, Latvia was just lucky' (Interviews 2013a, 2013f).

The setting of excessive budget targets served several purposes. First, it provided a safety margin against the unpredictability of Latvia's political process. According to a national official, tying politicians' hands simply made the budget drafting process much easier: 'Nobody really knows how one or another political power would behave before or after the budget adoption. Therefore, everything is planned with a certain reserve margin.' (Interview 2013g). That the excessive fiscal stringency also helped the government's commitment to comply with the Maastricht deficit criterion for joining the euro was confirmed by both the officials at the Commission and the government: 'All these plans on the euro made it possible to put the ruling powers in a kind of frame because there are always desires and needs...' (Interviews 2013a, 2013g). 
For the same 'hand-tying' reasons, the national authorities warmly welcomed the introduction of the Treaty on Stability, Coordination and Governance (the Fiscal Compact), and voluntarily overachieved its targets. In fact, Finance Minister Vilks argued for the need to secure fiscal discipline in the Constitution already in 2010 - before the adoption of the Fiscal Compact in 2012 and the Fiscal Discipline Law in $2013 .{ }^{2}$ Commenting on the Latvian Constitutional Court decision (2009) to repeal the planned pension cuts as they violated the pensioners' right for social security, Vilks was concerned that the Constitutional Court 'limited the scope of austerity' (tvnet.lv 2010).

As the Fiscal Compact stipulates, a country's Medium-Term Objective (MTO) budgetary deficit can be $-1 \%$ of GDP, provided that its public debt is significantly below $60 \%$ of GDP. With $46.0 \%$ of GDP in 2011 and 40.7\% of GDP in 2012 Latvia complied with this provision; however, the authorities chose to set the MTO at $-0.5 \%$ of GDP. Exercising a completely free choice in the matter, the Latvian government simply wanted to be 'more ambitious' (Interviews 2013a, 2013b, 2013f). Its rationale was to maximize the discipline imposed by an external constraint to save the authorities from any 'unnecessary' disputes and arguments, particularly from the opposition. According to a high-ranking official at the Ministry of Welfare: 'Before the Fiscal Discipline Law nobody really knew what the actual fiscal space was. Budgeting was a total chaos. Now you simply look at the number. Certainty is the most important thing' (Interview 2013g). According to a high-ranking Finance Ministry official, the Fiscal Compact guaranteed that 'the state would not return to 'fiscal blackguardism' anymore' (Interview 2013f).

However, the Latvian government did not use all the fiscal spending options allowed by the EU frameworks and the bailout conditionality. As stipulated by the 2010 Memorandum of Understanding, after the regular payback of the bailout loan, all 'unexpected' windfall revenue should have been used for three purposes: first, to achieve a lower-than-targeted budget deficit; second, to accelerate EU funds expenditure, and third, to increase funding for active labour market policies and social safety net measures (Supplemental Memorandum of Understanding 2009, 2010: 6). Nonetheless, rather than taking the opportunity for additional spending, the government chose to concentrate on early payback of the bailout loans.

\footnotetext{
${ }^{2}$ Latvia adopted the Fiscal Compact through the Fiscal Discipline Law that entered into force in March 2013.
} 
Regarding the excessive austerity measures, the Commission's position seems ambivalent. On the one hand, it endorsed the excessive fiscal policy targets pursued by the national authorities, as this helped to securitize against uncertainty (Interview 2013c). On the other hand, the Commission worried about the social costs of the consolidation measures: 'We have been emphasizing that more resources have to be allocated for social needs, and training for the unemployed... However, the government did not listen to us. Rather, they were looking forward to getting better budget numbers' (Interview 2013b).

It has to be noted that while overachieving the targets in some fiscal areas, the government breached them in others. Special attention should be given to the fact that these derogations occurred while Latvia was subject to post-programme surveillance. In mid-2012, inspired by Latvia's unexpected economic growth - at the time the highest in the EU - the authorities reopened the state budget. Additional spending amounting to $0.5 \%$ of GDP was allocated to a range of sectors, including healthcare, transport infrastructure, agriculture, demography and culture. According to PM Dombrovskis, this was the first time in five years when the government allowed itself to spend on priorities other than fiscal consolidation. However, in order to maintain fiscal discipline, the additional spending covered only a fraction of the wind-fall revenue (European Commission 2013c; Likumi.lv 2012). The government also set a three-year strategy to cut the flat personal income tax rate from $25 \%$ to $20 \%$. As these measures ran counter to both the National Reform Programme and the Country-Specific Recommendations (European Commission 2012c: 4; Ministry of Economics 2012: 28), they were strongly disapproved by the Commission (European Commission 2013c: 2).

Finally, taking advantage of the 'structural reform clause', which provided flexibility within the EU fiscal rules (European Commission 2015c: 10), Latvia exercised significant discretion in managing its pension system. In 2009, responding to the rapidly decreasing levels of social security contributions in the first pension pillar, the government had reduced the contribution rate to the second pillar from $8 \%$ to $2 \%$ (Volskis 2012: 9). Initially, it was planned that from 2013 contributions at a rate of $6 \%$ to the second pillar would be restored (Ministry of Economics 2012: 13). However, in order to accumulate additional assets in the social budget the government restored the contributions at only a $4 \%$ rate. Although, the Commission noted 
that the policy ran 'contrary to previous commitments by the authorities under the (BoP) program as well as more recent Country-Specific Recommendations', eventually, it not only accepted this move, but also allowed Latvia to derogate from the pre-set MTO of budget deficit of $0.5 \%$ of GDP for the amount needed to continue the pension reform (European Commission 2013c: 9; Interview 2013b). The above provides another example showing how the Commission compromised fiscal targets for the sake of a socially significant reform.

\section{Convergence towards the euro}

In order to the join the euro area, Latvia had to comply with the Maastricht convergence criteria with regard to the budget deficit, government debt, long-term interest rate and inflation. ${ }^{3}$ Since the other targets had already been covered by the consolidation programme, the main challenge was inflation - especially due to its dependence on a variety of factors beyond the control of the government. Lithuania's failure to qualify for the euro in 2006, by missing the inflation target by just $0.1 \%$, served as an effective reminder. Committed to avoiding a similar scenario by any means possible, the Latvian government started to plan a range of measures already in 2010. According to the Finance Minister, the control of inflation was a strategic priority, and compared to the other convergence targets - the most elusive one: 'The sooner we can push inflation down to a certain level, the better for all. Unless there is a strong tripartite collaboration and agreement between the government, employers, and employees, Latvia will not succeed in decreasing inflation to the level needed to introduce the euro' (Vilks 2010, 2011).

Most notably, inflation curbing involved ad hoc manipulations of the VAT rate. In 2010, aiming to increase the budget revenue, the government considered increasing VAT by one percentage point. Finance Minister Vilks proposed that VAT should be raised already in 2011, as raising it in 2012 could endanger compliance with the inflation target (Vilks 2010). Accordingly, from January 2011, the standard VAT rate was raised from $21 \%$ to $22 \%$, while

\footnotetext{
${ }^{3}$ The inflation rate may not be more than 1.5 percentage points above the rate of the three best performing member states. Government budget deficit as a percentage of GDP may not exceed 3\%, while government debt as a percentage may not exceed $60 \%$ of GDP. The long-term interest rate on government bonds may not be 2 percentage points above the rate of the three best performing MS. Finally, a member state has to participate in the ERMII mechanism for at least 2 years without severe tensions (European Commission 2015d).
} 
the lower VAT rate was raised from $10 \%$ to $12 \%$. In mid-2012, as predicted, the risk of missing the inflation target substantially increased, as Latvia had become one of the most rapidly growing economies in the EU. The government intervened again, cutting the VAT rate from $22 \%$ to $21 \%$. That the tax cut was euro-motivated was later confirmed by staff at the Commission and the Ministry of Economics (Interviews 2013b, 2013e). Eventually, Latvia met the inflation target with a $1.4 \%$ reserve; thus the estimated 0.5 percentage point effect of the VAT cut was not decisive for Latvia's qualification for the euro (European Commission 2013b: 30). However, as observed by two ECFIN economists, if the inflation benchmark had only been met with the help of the VAT cut, Latvia's euro application could have been rejected (Interviews 2013a, 2013c). Meanwhile, the Commission was concerned that the VAT cut limited opportunities to raise non-taxable thresholds and thus help low earners: 'There are too many low wages, and the tax wedge on labour is the highest for people with the lowest income. That was a good opportunity to help them a bit already then' (Interview 2013b).

\section{Governance of social policy: before and after accession to the euro}

Throughout the budget consolidation process, social policy was subordinated to the early payment of the bailout loans and accession to the euro. The authorities constantly ignored the Commission's social recommendations. Responding to lenders' criticisms, Latvia sought in its 2011 National Reform Programme to reduce the personal income tax burden on the economically active population and the population at risk of poverty, to raise the personal income allowance for dependants, to introduce a differentiated personal income tax, to provide social protection for families with children, and to encourage participation in the labour market (Ministry of Economics 2011). However, little of this was achieved in practice within the relevant time frame (European Commission 2012c; Interviews 2013a, 2013b).

The few successful social measures valued by the Commission included active labour market policies and training for the unemployed, initiatives to reverse the declining demographic trends (relaxing caps on maternity/paternity allowances, increasing minimum paternal benefits, child care benefits and PIT allowance for dependants), as well as the temporary public job programme Workplaces with Stipends, financed by the European Social Fund. Although, the programme was successful in helping the unemployed to mitigate the impact of 
the crisis (World Bank 2013a: 10), the Commission was concerned that it was used as a substitute for social assistance and did not address the main barriers to employment (European Commission 2013a: 17). Overall, Latvia's progress in social policy reforms remained unsatisfactory (European Commission 2013a: 4).

The picture changed after the government paid the lenders - and was admitted into the EuroArea (mid-2013). As the first Latvian budget drafted in the euro currency, the 2014 budget was also 'historic' in the sense that it prioritized reducing inequality and poverty, as well as improving the demographic situation (The Baltic Course 2013). Various social goals remained high on the political agenda over the coming years (Latvia.eu 2015; The Baltic Course 2014a, 2014b). Subsequently, several long-pending social policy reforms were adopted. The government introduced and extended a range of support measures for families with children, including maternity and paternity allowances, minimum monthly paternal and child care benefits and a Personal Income Tax (PIT) allowance for dependants. Partial indexation of pensions resumed and disability benefits were increased. The minimum wage was raised from EUR 320 to EUR 360 in 2015 and EUR 370 in 2016.

Notably, the social policy turn was not due to changes in the government. In fact, Unity (Vienotība) remained the main ruling party throughout the crisis. Even when PM Dombrovskis resigned after the Zolitūde shopping centre collapse in early 2013, the next Prime Minister Laimdota Straujuma (also from the Unity party) kept largely the same cabinet both before and after the 2014 elections (Ikstens 2015: 185).

At a general level, the social policy turn was a response to the far-and-wide reaching hardships imposed by the recession (Interviews 2013d, 2013g). Looking more closely, however, evidence suggests that the critical juncture was the negotiation process on GMI benefits and housing allowances between the lenders and the government. At the onset of the recession, following recommendations by the Commission and the World Bank, the GMI payment was taken over from the local municipalities by the government and the amount was substantially increased from LVL 27 to 45 (EUR 64) for children and to LVL 40 (EUR 57) for adults. However, as the economy improved, the government wanted to return to the previous arrangement. As admitted by Ilze Viṇkele, then Minister of Welfare, in a personal 
interview, all the lenders were strictly against phasing-out of the state financing and the decrease in the benefit amount. In turn, the municipalities, that would now have to take over the payments, ardently protested that the GMI benefit had to be eliminated altogether. According to the city mayors, people were 'becoming recipients of benefits over generations' and therefore did not want to work. As recalled by Minister Viņ̧,ele: 'Since we lacked any credible data as to what was actually going on with the GMI benefit recipients, I came up with an offer that if our current proposal was accepted, the government would study the GMI recipients, and then on the basis of the findings, would change the benefit system.' However, the lenders responded with a unanimous 'ultimatum' that the research had to be done by the World Bank, since the government allegedly lacked the skills, experience, and methodology to make such a study credible (Interview 2016).

In the meantime, despite the lenders' fierce objections, the government proceeded on its own. As from 2013, the authorities decreased the GMI to LVL 35 for all recipients and returned its administration back to the municipalities. As a 'significant reversal of gains achieved during and following the crisis' this policy was criticized by the World Bank (World Bank 2013a: 8; World Bank 2013b), the IMF and the Commission. The latter was concerned that the decision would 'maintain an uneven system with negative impact on benefit coverage and adequacy'(European Commission 2013c: 10; IMF 2013: 48).

The subsequent World Bank report Who is Unemployed, Inactive or Needy?, partially financed by the European Social Fund, plainly refuted the common wisdom in Latvian government and business circles that there was a large-scale dependence on social welfare benefits, which, in turn, made the poor unwilling to work (World Bank 2013c). As publicly admitted by Minister Viņķele, the study challenged the government's view on welfare, shifting it away from 'stereotypes, emotional opinions and 'even phobias' (Tapiņš 2013). Shortly after its publication, the Ministry of Welfare announced plans to increase the nontaxable income threshold, tax credits for dependents and the disabled, as well as the minimum wage (Dārziņa 2013). The Latvian government continued this progressive policy course even after the end of the Commission's close monitoring in 2014 - notably, in taxation. While the wave of tax credits and allowances for the poor and unprotected represented progressive 
taxation 'by stealth', the measures adopted from 2016 did so more openly (The Baltic Course 2015; Vanags and Zasova 2015).

\section{Conclusion}

This case study of Latvia's economic governance, first, gives in-depth insight into how EU rules may be cherry-picked and instrumentalised by national authorities. The Latvian government took advantage of all three governance frameworks to which it was subject - the Balance-of-Payments programme, the Maastricht convergence criteria and the European Semester, according to its priorities at the time. Initially, the government mainly focused on fiscal consolidation and the early payback of the loans. In order to do this, the Balance-ofPayments programme and the Fiscal Compact were instrumentalised, by pushing fiscal targets to the extreme. However, once the authorities had accomplished the early loan repayment to the IMF and paid $75 \%$ of the loan back to the Commission (thus entering the post-programme surveillance phase with a significantly reduced level of monitoring), the government shifted its reform focus to euro convergence. In order to push down inflation and comply with the Maastricht price stability criterion, the government cut VAT. Meanwhile, against a backdrop of self-imposed austerity, the authorities constantly ignored the Commission's advocacy to take care of the poor and vulnerable groups.

Nonetheless, in 2013, as Latvia received the green light to join the Euro Area, the Commission's social policy recommendations finally started to gain traction - without major changes in government. During the subsequent years, Latvia adopted a range of progressive reforms targeted at reducing poverty and inequality. As the paper shows, to a considerable extent this progress in Latvia's social policy was a result of the advocacy by the international lenders - notably, the Commission, the World Bank and the IMF. In response to the government's plans to phase out the state financing of social benefits, the international lenders - of whom the Commission was by far the largest - unanimously forced the government to commission a study by the World Bank. The subsequent report effectively refuted the common wisdom on welfare provision among the Latvian elites, and served as a basis for far-reaching social reforms. 
However, 'harder' social policy governance does not always lead to more compliance. In fact, the government continued the progressive policy reforms even after 2014 when close monitoring ended. In addition, the authorities exercised substantial discretion in 'soft' social policy, as well as in 'hard' fiscal policy areas, such as budgeting, pensions, taxation and spending - even when subject to the Balance-of-Payments programme and post-programme surveillance. Yet to the extent that the formal overachievements in some policy areas were used implicitly as a justification for the derogations in others, the limited effectiveness of social policy governance might be a consequence of the one-size-fits-all operation of the fiscal and euro-related governance frameworks, as these were pushed to the extreme by the national authorities.

This case study has significant implications for EU economic governance as a whole. As the evidence shows, hierarchical governance structures not only suffer from an inability to address local needs and challenges, but also from ineffectiveness in operation. When designing one-size-fits-all fiscal rules or the convergence criteria, EU policy makers could not have anticipated either the socio-economic conditions of the specific member state, or the preferences of its governing élites. Additional uncertainty came about as a result of opportunistic cherry-picking and instrumentalisation of the frameworks on the part of the government. Meanwhile, the Commission's advocacy of social policy in Latvia serves as a positive example of how its governance approach can be dynamically adjusted according to experience on the ground. Responding to the fiscal radicalism pursued by the authorities, the Commission became a social policy advocate even before the broader social agenda of the European Semester was first formalized in the 2012 Annual Growth Survey (European Commission 2012a). Latvia's social policy still significantly falls short of the European Semester benchmarks. The Commission has concluded that little progress had been made on a number of big-ticket 'quality-of-life improving' reforms to tackle high social inequality and poverty (European Commission 2014; European Commission 2015a). Nonetheless, social policy in Latvia has become increasingly progressive since the economic crisis - to a large extent, because of Commission's pressure. The Latvian experience may send a positive signal to other countries in the EU's periphery, struggling with malfunctioning social policy systems, whether in terms of poor targeting or low spending - such as the other neoliberal Baltic countries and the weak states in South-Eastern Europe (i.e. Romania, Bulgaria and Croatia) (Bohle and Greskovits 2012). As the Latvian case shows, if electoral support for 
economic redistribution is low, pressure from external institutions can play an important role to instigate change.

\section{References}

Aslund, A. (2013) Why Austerity Works and Stimulus Doesn't, 7 January 2013, Bloomberg View, available at http://www.bloombergview.com/articles/2013-01-07/why-austerity-works-and-fiscal-stimulus-doesn-t (accessed January 2016).

Aslund, A. and Dombrovskis, V. (2011) How Latvia Came Through the Financial Crisis, Washington, D.C.: Institute of International Economics.

Auers, D. (2013) in S. Berglund, J. Ekman, K. Deegan-Krausa, and T. Knutsen (eds). The Handbook of Political Change in Eastern Europe. Cheltenham, UK: Edward Elgar Publishing.

Austers, A. (2014) 'How great is Latvia’s success story?', Intereconomics 49(4): 228-238.

Bekker, S. (2013) The EU's Stricter Economic Governance: A Step Towards More Binding Coordination of Social Policies?

Blyth, M. (2013) Austerity: The History of a Dangerous Idea, New York: Oxford University Press.

Bohle, D. and Greskovits, B. (2012) Capitalist Diversity on Europe's Periphery, Ithaca and London: Cornell University Press.

Crespy, A. and Menz, G. (2015) 'Commission Entrepreneurship and the Debasing of Social Europe Before and After the Eurocrisis', JCMS: Journal of Common Market Studies 53(4): 753-768.

Dandashly, A. and Verdun, A. (2015) 'Boarding the Euro Plane: Euro Adoption in the Czech Republic and Slovakia', Review of European and Russian Affairs 9(2), 1-26.

Dārziņa, L. (2013) Pasaules Bankas pētījumu Labklājības ministrija izmantos sociālās drošības politikas pilnveidei, 2013, LVPORTĀLS, available at http://www.lvportals.lv/visi/likumi-prakse/255607pasaules-bankas-petijumu-labklajibas-ministrija-izmantos-socialas-drosibas-politikas-pilnveidei/ (accessed September 2016).

de la Porte, C. and Heins, E. (2014) 'Game Change in EU Social Policy: From Optional Re-calibration to Coercive Retrenchment', in E. Xiarchogiannopoulou and M. Rodrigues (eds). The Eurozone crisis and the transformation of democracy. Burlington: Ashgate Publishing Company.

Degryse, C., Jepsen, M. and Pochet, P. (2013) The Euro crisis and its impact on national and European social policies, Brussels.

Dyson, K. and Featherstone, K. (1996) 'Italy and EMU as a "Vincolo Esterno": empowering the technocrats, transforming the state', South European Society and Politics 1(2): 272-299.

European Commission (2011) Annual Growth Survey: advancing the EU's comprehensive response to the crisis, Brussels, available at http://ec.europa.eu/europe2020/pdf/en_final.pdf (accessed April 2016). 
European Commission (2012a) Annual Growth Survey, Brussels, available at http://ec.europa.eu/europe2020/pdf/ags2012_en.pdf (accessed April 2016).

European Commission (2012b) EU Balance-of-Payments Assistance for Latvia: Foundations of Success, available at http://ec.europa.eu/economy_finance/publications/occasional_paper/2012/pdf/ocp120_en.pdf (accessed December 2015).

European Commission (2012c) Recommendation for a Council recommendation on Latvia's 2012 national reform programme and delivering a Council opinion on Latvia's Convergence Programme for 2012 2015, Brussels, available at http://ec.europa.eu/europe2020/pdf/nd/csr2012_latvia_en.pdf (accessed January 2016).

European Commission (2013a) Commission Staff Working Document: Assessment of the 2013 National Reform Programme and Convergence Programme for Latvia, Brussels: European Commission, available at http://ec.europa.eu/europe2020/pdf/nd/swd2013_latvia_en.pdf (accessed March 2016).

European Commission (2013b) Convergence Report 2013 on Latvia, Brussels: European Commission, available at http://ec.europa.eu/economy_finance/publications/european_economy/2013/pdf/ee3_en.pdf (accessed December 2015).

European Commission (2013c) EU BoP Assistance to Latvia - Second Review Under Post-programme Surveillance, Brussels: Directorate General, Economic and Financial Affairs, available at http://ec.europa.eu/economy_finance/eu_borrower/balance_of_payments/pdf/lv_efc_note_2nd_pps_mi ssion_en.pdf (accessed December 2015).

European Commission (2014) Recommendation for a Council recommendation on Latvia's 2014 national reform programme and delivering a Council opinion on Latvia's 2014 stability programme, Brussels: European Commission, available at http://ec.europa.eu/europe2020/pdf/csr2014/csr2014_latvia_en.pdf (accessed April 2016).

European Commission (2015a) Commission Staff Working Document: Country Report Latvia 2015, Brussels, available at http://ec.europa.eu/europe2020/pdf/csr2015/cr2015_latvia_en.pdf (accessed March 2015).

European Commission (2015b) Making it Happen: the European Semester, 2015, Europe 2020, available at http://ec.europa.eu/europe2020/making-it-happen/index_en.htm (accessed December 2015).

European Commission (2015c) Making the Best Use of the Flexibility within the Existing Rules of the Stability and Growth Pact, Strasbourg, available at http://eur-lex.europa.eu/legalcontent/EN/TXT/PDF/?uri=CELEX:52015DC0012\&from=EN (accessed April 2016).

European Commission (2015d) Who can join and when?, 2015, Who can join and when?, available at http://ec.europa.eu/economy_finance/euro/adoption/who_can_join/index_en.htm (accessed December 2015).

European Court of Auditors (2015) Financial Assistance Provided to Countries in Difficulties, Luxemburg, available at

http://www.eca.europa.eu/Lists/ECADocuments/SR15_18/SR_CRISIS_SUPPORT_EN.pdf (accessed March 2016).

Ferrera, M. and Gualmini, E. (2004) Rescued by Europe?: Social and Labour Market Reforms in Italy from Maastricht to Berlusconi, 1 edition., Amsterdam: Amsterdam University Press.

George, A. L. and Bennett, A. (2005) Case Studies and Theory Development in the Social Sciences, MIT Press.

Hacker, B. (2012) The End of the European Social Model as We have Envisioned it? Political Economy Principles in Europe may be Changed by the Economic Crisis Governance, in 2012, University of Sheffield, 1-3 July.

Ikstens, J. (2015) 'Latvia', European Journal of Political Research Political Data Yearbook 54(1): 181-189. 
IMF (2013) Republic of Latvia: Ex Post Evaluation of Exceptional Access Under the 2008 Stand-By Arrangement; Public Information Notice on the Executive Board Discussion; and Statement by the Executive Director for the Republic of Latvia, International Monetary Fund.

Interview (2013a) Economist, European Commission.

Interview (2013b) Economist, European Commission.

Interview (2013c) Economist, European Commission.

Interview (2013d) Economist, European Commission.

Interview (2013e) Official, Ministry of Economics, Republic of Latvia.

Interview (2013f) Official, Ministry of Finance, Republic of Latvia.

Interview (2013g) Official, Ministry of Welfare, Republic of Latvia.

Interview (2016) Ilze Viṇkele, Minister of Welfare, Republic of Latvia (2011-2014).

Joerges, C. (2014) 'Law and Politics in Europe's Crisis: On the History of the Impact of an Unfortunate Configuration', Constellations 21(2): 249-261.

Krugman, P. (2009) Latvia is the new Argentina (slightly wonkish), 2009, Paul Krugman Blog, available at http://krugman.blogs.nytimes.com/2008/12/23/latvia-is-the-new-argentina-slightly-wonkish/ (accessed December 2015).

Laffan, B. and Schlosser, P. (2015) The Rise of a Fiscal Europe? Negotiating Europe's New Economic Governance, Florence School of Banking \& Finance (FBF).

Lagarde, C. (2012) Latvia and the Baltics - a Story of Recovery. Speech, International Monetary Fund, available at https://www.imf.org/external/np/speeches/2012/060512.htm.

Latvia.eu (2015) Budget for 2016 approved by the Saeima, 1 December 2015, [Latvia.eu], available at http://www.latvia.eu/news/budget-2016-approved-saeima (accessed March 2016).

Likumi.lv (2012) Budžeta grozījumi: palielinot izdevumus, visus virsplāna ieṇēmumus netērēs, 2012, Latvijas Vēstneša portāls, available at http://www.lvportals.lv/visi/likumi-prakse/250540-budzeta-grozijumipalielinot-izdevumus-visus-virsplana-ienemumus-neteres/ (accessed March 2016).

Lütz, S. and Kranke, M. (2014) 'The European rescue of the Washington Consensus? EU and IMF lending to Central and Eastern European countries', Review of International Political Economy 21(2): 310-338.

Milne, R. (2013) 'Latvia: Reaching for the Euro', Financial Times 23 April, available at http://www.ft.com/intl/cms/s/0/5df14d34-a776-11e2-bfcd-00144feabdc0.html\#axzz436nUHu2w (accessed March 2016).

Ministry of Economics (2011) National Reform Programme of Latvia for the Implementation of the 'Europe 2020'strategy, Riga, available at http://ec.europa.eu/europe2020/pdf/nrp/nrp_latvia_en.pdf (accessed March 2016).

Ministry of Economics (2012) Progress Report on the Implementation of the National Reform Programme of Latvia within the 'Europe 2020' Strategy, Riga, available at http://ec.europa.eu/europe2020/pdf/nd/nrp2012_latvia_en.pdf (accessed February 2016).

Pochet, P. and Degryse, C. (2012) The Programmed Dismantling of the 'European Social Model', 212-217.

Roubini, N. (2008) EconoMonitor, available at http://www.economonitor.com/nouriel/2009/06/10/latviascurrency-crisis-is-a-rerun-of-argentinas/ (accessed December 2015). 
Scharpf, F. (2014) 'Legitimacy intermediation in the multilevel European polity and its collapse in the eurocrisis. Comment', in J. E. Fossum and A. J. Menéndez (eds). The European Union in crises or the European Union as crises?. pp. 93-157.

Schmidt, V. (2014) Building legitimacy in the EU 'by stealth' in the Eurozone crisis: EU institutional actors' differential pathways to legitimation, in 2014, Gothenburg.

Schmidt, V. (2015) 'Changing the policies, politics, and processes of the Eurozone in crisis: will this time be different?', in D. Natali and B. Vanhercke (eds). Social policy in the European Union: state of play 2015. European Trade Union Institute, European Social Observatory, pp. 33-64.

Schoukens, P. (2013) From Soft Monitoring to Enforceable Action: A Quest for New Legal Approaches in the EU Fight against Social Exclusion, available at https://lirias.kuleuven.be/handle/123456789/404634 (accessed April 2016).

Spiegel, P., Donnan, S. and Chassany, A.-S. (2015) 'IMF criticises Greece bailout deal with EU', Financial Times 15 July, available at http://www.ft.com/intl/cms/s/0/444a0bc8-2a46-11e5-8613e7aedbb7bdb7.html\#axzz45sq5PFOr (accessed April 2016).

Supplemental Memorandum of Understanding (2009) First addendum to the Memorandum of Understanding between the European Union and the Republic of Latvia, European Commission, available at http://ec.europa.eu/economy_finance/eu_borrower/balance_of_payments/pdf/mou_add1_bop_latvia_en .pdf (accessed December 2015).

Supplemental Memorandum of Understanding (2010) Second addendum to the Memorandum of Understanding between the European Union and the Republic of Latvia, European Commission, available at http://ec.europa.eu/economy_finance/eu_borrower/balance_of_payments/pdf/mou_add2_bop_latvia_en .pdf (accessed December 2015).

Tapiņš, A. (2013) The government prepares to tackle inequality after years of ignoring advice - Re:Baltica, 2013, Re:Baltica, available at http://www.rebaltica.lv/en/important/a/949/the_government_prepares_to_tackle_inequality_after_years _of_ignoring_advice.html (accessed September 2016).

The Baltic Course (2013) Latvia's PM calls 2014 budget 'historic', 2013, available at http://www.balticcourse.com/eng/finances/?doc=82199 (accessed March 2016).

The Baltic Course (2014a) Reirs names fiscal discipline and reducing inequality as his priorities in Latvia, 2014, available at http://www.baltic-course.com/eng/finances/?doc=98493 (accessed April 2016).

The Baltic Course (2014b) Vilks: budget priorities in 2015 will focus on defense, healthcare and social inequality, 2014, available at http://www.baltic-course.com/eng/finances/?doc=97642 (accessed March 2016).

The Baltic Course (2015) Solidarity tax to be charged on high salaries in Latvia as of 2016, 2015, The Baltic Course | Baltic States news \& analytics, available at http://www.balticcourse.com/eng/legislation/?doc=113639 (accessed January 2016).

Traynor, I. (2012) 'Latvia still keen to join single currency despite euro crisis', The Guardian 19 September, available at http://www.theguardian.com/world/2012/sep/19/latvia-keen-join-euro (accessed December 2015).

Trubek, D. and Trubek, L. (2005) 'Hard and Soft Law in the Construction of Social Europe: the Role of the Open Method of Co-ordination - Trubek - 2005 - European Law Journal - Wiley Online Library', European Law Journal 11(3): 343-364.

tvnet.lv (2010) Vilks: Satversmes tiesa ierobežo iespēju taupīt | Financenet | TVNET, 2010, available at http://financenet.tvnet.lv/viedokli/358745-vilks_satversmes_tiesa_ierobezo_iespeju_taupit (accessed June 2016). 
Vanags, A. and Zasova, A. (2015) Latvia Stumbling Towards Progressive Income Taxation, BICEPS, available at http://freepolicybriefs.org/2015/11/16/latvia-stumbling-towards-progressive-income-taxation-2/ (accessed March 2016).

Vandenbroucke, F., Diris, R. and Verbist, G. (2013) Excessive Social Imbalances and the Performance of Welfare States in the EU.

Vanhercke, B., Zeitlin, J. and Zwinkels, A. (2015) Further socializing the European Semester, available at https://www.accesseurope.org/research/publications/5-policy-report/15-further-socializing-theeuropean-semester (accessed March 2016).

Vilks, A. (2010) PVN jāpalielina no nākamā gada, nevis 2012. gadā, available at https://www.youtube.com/watch?v=1HHQObjkLkA (accessed December 2015).

Vilks, A. (2011) 'A.Vilks: Inflācijai gada otrajā pusē vajadzētu samazināties’, LTV Panorāma, available at https://www.youtube.com/watch?v=5kB8Kbv5zEk.

Volskis, E. (2012) Reforms of Baltic States Pension Systems: Challenges and Benefits, in 2012, Tallin: Estonian Ministry of Finance and EBRD, available at http://www.ebrd.com/downloads/news/pension-system.pdf (accessed April 2016)

Woolfson, C. and Sommers, J. (2016) 'Austerity and the Demise of Social Europe: The Baltic Model versus the European Social Model', Globalizations 13(1): 78-93.

World Bank (2013a) Expenditure and Performance of Welfare Benefits and Employment Programs, available at http://www.lm.gov.lv/upload/aktualitates/lv_expenditure_and_performance.pdf (accessed December 2015).

World Bank (2013b) Latvia GMI Program: Main Design Characteristics and Comparison with Minimum, available at http://www.lm.gov.lv/upload/aktualitates/lv_gmi_note_270513.pdf (accessed December 2015).

World Bank (2013c) Latvia: Who is Unemployed, Inactive or Needy?, 2013, available at http://www.worldbank.org/en/news/feature/2013/05/17/latvia-who-is-unemployed-inactive-or-needy (accessed June 2016).

Zeitlin, J. and Vanhercke, B. (2014) Socializing the European Semester? Economic Governance and Social Policy Coordination in Europe 2020, Swedish Institute for European Policy Studies. 